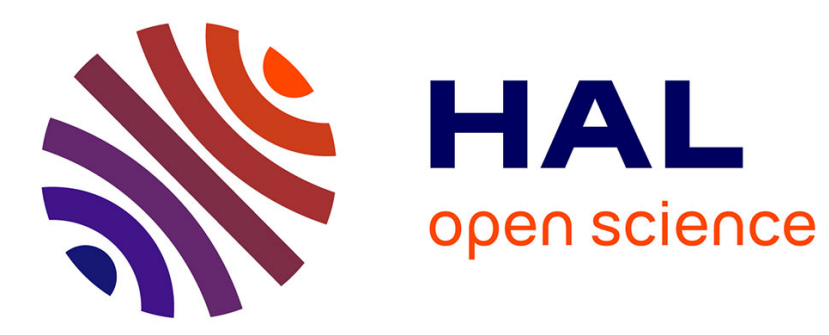

\title{
Redox control of sulfur degassing in silicic magmas
}

Bruno Scaillet, Béatrice Clémente, Bernard W. Evans, Michel Pichavant

\section{To cite this version:}

Bruno Scaillet, Béatrice Clémente, Bernard W. Evans, Michel Pichavant. Redox control of sulfur degassing in silicic magmas. Journal of Geophysical Research : Solid Earth, 1998, 103 (B10), pp.23,93723,949. 10.1029/98JB02301 . insu-00717692

\section{HAL Id: insu-00717692 \\ https://hal-insu.archives-ouvertes.fr/insu-00717692}

Submitted on 13 Jul 2012

HAL is a multi-disciplinary open access archive for the deposit and dissemination of scientific research documents, whether they are published or not. The documents may come from teaching and research institutions in France or abroad, or from public or private research centers.
L'archive ouverte pluridisciplinaire $\mathbf{H A L}$, est destinée au dépôt et à la diffusion de documents scientifiques de niveau recherche, publiés ou non, émanant des établissements d'enseignement et de recherche français ou étrangers, des laboratoires publics ou privés. 


\title{
Redox control of sulfur degassing in silicic magmas
}

\author{
Bruno Scaillet and Béatrice Clemente \\ Centre de Recherches sur la Synthèse et la Chimie des Mınéraux, CNRS, Orléans, France \\ Bernard W. Evans \\ Department of Geologıcal Sciences, University of Washington, Seattle \\ Michel Pichavant \\ Centre de Recherches sur la Synthèse et la Chımıe des Minéraux, CNRS, Orléans, France
}

\begin{abstract}
Explosive eruptions involve mainly silicic magmas in which sulfur solubility and diffusivity are low. This inhibits sulfur exsolution during magma uprise as compared to more mafic magmas such as basalts. Silicic magmas can nevertheless liberate large quantities of sulfur as shown by the monitoring of $\mathrm{SO}_{2}$ in recent explosive silicic eruptions in arc settings, which invariably have displayed an excess of sulfur relative to that calculated from melt degassing. If this excess sulfur is stored in a fluid phase, it implies a strong preference of sulfur for the fluid over the melt under oxidized conditions, with fluid/melt partition coefficients varying between 50 and 2612, depending on melt composition. Experimentally determined sulfur partition coefficients for a dacite bulk composition confirm this trend and show that in volcanic eruptions displaying excess gaseous sulfur, the magmas were probably fluid-saturated at depth. The experiments show that in more reduced silicic magmas, those coexisting only with pyrrhotite, the partition coefficient decreases dramatically to values around 1, because pyrrhotite locks up nearly all the sulfur of the magma. Reevaluation of the sulfur yields of some major historical eruptions in the light of these results shows that for oxidized magmas, the presence of 1-5 wt \% fluid may indeed account for the differences observed between the petrologic estimate of the sulfur yield and that constrained from ice core data. Explosive eruptions of very large magnitude but involving reduced and cool silicic magmas, such as the Toba or the Bishop events, release only minor amounts of sulfur and could have consequently negligible long-term (years to centuries) atmospherical effects. This redox control on sulfur release diminishes as the melt composition becomes less silicic and as temperature increases, because both factors favor more efficient melt sulfur degassing owing to the increased diffusivity of sulfur in silicate melts under such conditions.
\end{abstract}

\section{Introduction}

Eruptions involving silicic arc magmas have potentially major climatic consequences because they are able to inject sulfur well into the stratosphere [e.g., Bluth et al, 1993], as illustrated by the recent eruptions of El Chichón and Pinatubo, whose atmospheric sulfur contributions could be accurately characterized through remote-sensing methods such as the Total Ozone Mapping Spectrometer (TOMS) on board the NASA Nimbus 7 satellite [Krueger et al., 1995]. The sulfur released by volcanic activity, either as $\mathrm{SO}_{2}$ or $\mathrm{H}_{2} \mathrm{~S}$, is soon converted into sulphate aerosols, mainly $\mathrm{H}_{2} \mathrm{SO}_{4}$, through photochemical reactions with water vapor. This results in an increase in the thickness of the stratospheric layer of aerosol, which is thought to enhance the cooling of the underlying troposphere by backscattering of solar radiation. Subsequent fallout of these sulfuric acid droplets produces acid spikes in ice core records, which have proved to be a major assist in

Copyright 1998 by the American Geophysical Union.

Paper number $98 \mathrm{JB} 02301$.

0148-0227/98/98JB-02301\$09.00 establishing correlations between global climate changes and past major volcanic events [Hammer et al., 1980; Legrand and Delmas, 1987; Zielinski et al., 1994]. Such a record also provides a quantitative estimate of the amounts of volcanic aerosol loaded into the stratosphere by important volcanic eruptions. Volcanic sulfur yields have also been estimated by comparing the sulfur content of degassed (matrix glass) and undegassed (glass inclusions) quenched melts, scaled by the mass of erupted magma [Devine et al., 1984; Palais and Sigurdsson, 1989]. The latter method is the only one available for directly quantifying the sulfur yield of volcanic eruptions having occurred before remote-sensing techniques became operative.

Although the sulfur yields based on ice core methods were in some cases found to disagree with those obtained from the petrological approach [e.g., Palais and Sigurdsson, 1989], the rather large error associated to the former method prevented from concluding about the origin of this disagreement. In contrast, the much more precise sulfur yields obtained from remote-sensing methods leave no doubt about the existence of such a difference, TOMS-based estimates of sulfur yields typically exceeding petrologic ones by 1-2 orders of magnitude [e.g., Westrich and Gerlach, 1992]. The source of 
this excess sulfur in silicic magmas has been a matter of debate [Westrich and Gerlach, 1992; Rutherford and Devine, 1996]. Several possibilities have been considered, including sulfur degassed from non erupted magma, sulfur released from the breakdown of sulfur-bearing phases [Devine et al., 1984] such as anhydrite and pyrrhotite, sulfur released on mixing between reduced and oxidized magmas [Matthews et al., 1992; Kress, 1997], and the presence of a sulfur-bearing fluid phase coexisting at depth with the magma prior to eruption [ $\mathrm{Luhr}$ et al., 1984; Williams et al., 1990; Andres et al., 1991; Gerlach and McGee, 1994; Gerlach et al., 1994, 1996; Wallace and Gerlach, 1994]. A growing body of evidence for fluidsaturated magmas in arc settings [Sisson and Grove, 1993; Wallace et al., 1995] lends support to the latter hypothesis. However, although the general behavior of sulfur in magmas is well understood [Carroll and Rutherford, 1987, 1988; Luhr, 1990], our knowledge about the partitioning of sulfur between silicate melts and fluids, and thus the evaluation of the potential role of this mechanism in volcanic eruptions, remains very poor. This in turn seriously complicates any attempts to draw connections between volcanic activity and global climate perturbations.

In this report we evaluate sulfur partitioning in several recent volcanic eruptions that have had their sulfur yields monitored by remote-sensing methods. The results are compared to experimentally determined sulfur partition coefficients, obtained from phase equilibrium experiments carried out on the dacite erupted on June 15, 1991, at Mount Pinatubo, Philippines. We then evaluate the potential role of the fluid phase for sulfur release during some important past volcanic eruptions. We conclude that major volcanic explosions involving fluid-bearing but relatively reduced silicic magmas, such as the Bishop tuff or the Toba event, will have negligible to moderate climatic impacts.

\section{Sulfur Partitioning in Present-Day Volcanic Eruptions}

Assuming that the excess sulfur was stored in a coexisting fluid phase, Gerlach et al. [1996] have calculated a fluid/melt sulfur partitioning ratio for the Pinatubo dacite erupted on June 15, 1991, of about 720 (Table 1). We have performed similar calculations for other volcanic eruptions for which remote-sensing sulfur estimates as well as constraints on pre eruption conditions are available. Such combined types of data are scarce, however, being available only for Mount St. Helens (1980), Redoubt (1989-1990), El Chichón (1982), and Nevado del Ruiz (1985) eruptions, in addition to Pinatubo (Table 1). All the magmas have andesitic to dacitic bulk compositions and are erupted in zones of tectonic convergence. To calculate the sulfur partitioning, we assume that the fluid phase consists predominantly of $\mathrm{H}_{2} \mathrm{O}, \mathrm{CO}_{2}$, and $\mathrm{H}_{2} \mathrm{~S}$ gas species, which are by far the three dominant species of magmatic fluids [Symmonds et al., 1994]. Thus we have the following relation:

$$
\mathrm{XH}_{2} \mathrm{O}+\mathrm{XCO}_{2}+\mathrm{XH}_{2} \mathrm{~S}=1
$$

where $\mathrm{X}_{\mathrm{i}}$ is the mole fraction of the species $i$ in the fluid phase. Provided that the mole fraction of $\mathrm{H}_{2} \mathrm{O}$ in the fluid phase is known (i.e., from experimental phase equilibria) and that constraints on the $\mathrm{C} / \mathrm{S}$ ratio are available (i.e., from remotesensing measurements that gives $\mathrm{CO}_{2} / \mathrm{SO}_{2}$ ) equation (1) can be solved for $\mathrm{XH}_{2} \mathrm{~S}$, and the concentration of sulfur in the fluid phase can be calculated. The ratio between $S$ in melt, as estimated from glass inclusion analyses, and $S$ in fluid, in turn, gives the partition coefficient of sulfur between the melt and the fluid at pre eruption conditions. The amount of fluid coexisting with the magma at depth can then be calculated using the restored fluid composition and scaling with the amount of emitted sulfur detected by remote-sensing tools. Finally, the ratio mass of fluid/(mass of erupted magma) gives the wt \% fluid coexisting at depth in the magma chamber. Since the TOMS-based estimates of sulfur may not record the sulfate adsorbed on ashes directly carried down to the ground following eruption, as shown by Varekamp et al. [1984] for the El Chichón eruption and as suggested for most other eruptions (J. Luhr, personal communication, 1998), the fluid wt $\%$ listed in Table 1 are probaly minimum values (see also Krueger et al. [1995] for TOMS limitations in volcanic $\mathrm{SO}_{2}$ retrievals).

Table 1. Sulfur Fluid/Melt Partition Coefficients From Recent Volcanic Eruptions

\begin{tabular}{|c|c|c|c|c|c|c|c|c|c|c|c|c|}
\hline Volcano & $\begin{array}{l}P_{,}^{\mathrm{a}} \\
\mathrm{MPa}\end{array}$ & $\begin{array}{l}T_{,}^{\mathbf{a}} \\
{ }^{\circ} \mathrm{C}\end{array}$ & $\begin{array}{c}\triangle \mathrm{NNO},{ }^{\mathrm{b}} \\
\text { bars }\end{array}$ & $\begin{array}{c}\mathrm{XH}_{2} \mathrm{O} \text {, } \\
\text { (in Fluid) }\end{array}$ & $\begin{array}{c}\mathrm{XSO}_{2} \\
\text { (in Fluid) }\end{array}$ & $\begin{array}{l}\text { Fluıd, } \\
\text { wt \% }\end{array}$ & $\begin{array}{l}\mathrm{SiO}_{2,}{ }^{\mathrm{c}} \\
\mathrm{wt} \%\end{array}$ & $\begin{array}{c}\text { Bulk S, } \\
\text { wt } \%\end{array}$ & $\begin{array}{c}\text { S Melt, } \\
\text { ppm }\end{array}$ & $\begin{array}{l}\text { Anh, } \\
\text { wt } \%\end{array}$ & $\begin{array}{c}\mathrm{Po}^{f} \\
\text { wt \% }\end{array}$ & $\mathrm{S}_{\text {fluid }} / \mathrm{S}_{\text {melt }}$ \\
\hline Pinatubo & 220 & 760 & 1.7 & 0.80 & 0.04 & 3.6 & 77.8 & 030 & 75 & 0.3 & - & 720 \\
\hline St. Helens & 220 & 920 & 1.0 & 0.67 & 0.04 & 14 & 73.5 & 0.04 & 68 & $?$ & $<01$ & 650 \\
\hline El Chichón & 200 & 800 & 1.2 & 0.95 & 0.01 & 26.3 & 69.0 & 1.00 & 200 & 10 & $<0.1$ & 50 \\
\hline Redoubt & 200 & $>850$ & 20 & 0.60 & 0.13 & 1.0 & 77.0 & 060 & 60 & $?$ & - & 2612 \\
\hline Redoubt & 200 & $>900$ & 2.0 & 0.60 & 013 & 1.0 & 69.0 & 0.60 & 870 & $?$ & - & 180 \\
\hline Nevado del Ruiz & $<200$ & $>900$ & 1.5 & 050 & 0.25 & 3.0 & 76.0 & 0.94 & 90 & $<0.1$ & $<0.1$ & 2452 \\
\hline Nevado del Ruiz & $<200$ & $>900$ & 1.5 & 0.50 & 0.25 & 3.0 & 64.0 & 0.94 & 700 & $<0.1$ & $<01$ & 315 \\
\hline
\end{tabular}

${ }^{a_{P}}$ and $T$ correspond to the pre-eruption pressures and temperatures, respectively.

${ }^{\mathrm{b}} \mathrm{NNO}=\log f \mathrm{O}_{2}$ magma $-\log f \mathrm{O}_{2}$ NNO calculated at the preeruption $P$ and $T$.

"Silica content (anhydrous basis) of the residual melt.

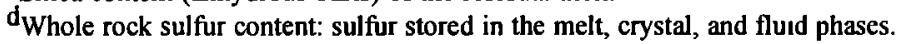

esulfur content of undegassed melt obtained from glass inclusion analyses.

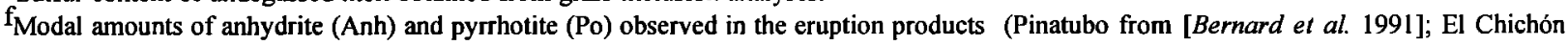
from [Luhr et al. 1984], Nevado del Ruiz from [Fournelle 1990]). 
For Mount St. Helens, experimental evidence [Rutherford and Devine, 1988] shows that prior to May 18, 1980 eruption the mole fraction of $\mathrm{H}_{2} \mathrm{O}$ in the fluid phase was 0.67 , assuming that the magma was volatile-saturated. Ground-based measurements of volcanic gas emissions with a correlation spectrometer (COSPEC) showed an average ratio of $\mathrm{CO}_{2} / \mathrm{SO}_{2}$ (in this work all $\mathrm{CO}_{2} / \mathrm{SO}_{2}$ ratios are reported on a molar basis) of 8 [Gerlach and McGee, 1994]. For the 1990-1991 Redoubt eruptions we use a $\mathrm{CO}_{2} / \mathrm{SO}_{2}$ ratio of 2 , as constrained by COSPEC data [Casadevall et al., 1994] and an $\mathrm{XH}_{2} \mathrm{O}=0.6$, the minimum required for amphibole stability in shallow level andesitic to dacitic magma chambers [e.g., Rutherford and Devine, 1988]. COSPEC measurements on Nevado del Ruiz yielded a $\mathrm{CO}_{2} / \mathrm{SO}_{2}$ ratio of 1 [Williams et al., 1992]. For $\mathrm{El}$ Chichón, the $\mathrm{CO}_{2} / \mathrm{SO}_{2}$ ratio is not known. However, measured molar $\mathrm{CO}_{2} / \mathrm{SO}_{2}$ ratios of volcanic emissions in convergent tectonic settings fall in the range 2-15 [Williams et al., 1992], and so for $\mathrm{El}$ Chichón we assume a $\mathrm{CO}_{2} / \mathrm{SO}_{2}$ ratio of 7 . Additional constraints were $\mathrm{XH}_{2} \mathrm{O}=0.95$ for El Chichón, as phase equilibria suggest $[\mathrm{Luhr}, 1990]$, and $\mathrm{XH}_{2} \mathrm{O}=0.5$ for Nevado del Ruiz because of the observed scarcity of amphibole in the eruptive products [Sigurdsson et al., 1990], which suggests pre eruption conditions on the verge of the stability field of amphibole. In both the Nevado del Ruiz and Redoubt eruptions there is petrologic evidence for magma mixing before eruption [Sigurdsson et al., 1990; Gourgaud and Thouret, 1990; Swanson et al., 1994], and glass sulfur contents are highly variable with the lowest sulfur contents in the most silicic glasses [Sigurdsson et al., 1990; Gerlach et al., 1994]. In these two cases we give sulfur partition coefficients for both the maximum and minimum melt sulfur contents reported.

Table 1 shows that the restored amount of fluid phase ranges between 1 and $4 \mathrm{wt} \%$ of the erupted mass of magma, except for El Chichòn whose exceptionally high sulfur yield as compared to the relatively small mass of erupted magma translates into a very large amount of fluid, in excess of $20 \mathrm{wt} \%$ (but see below). These estimates are comparable to those calculated for some silicic magmas [Wallace et al., 1995]. The mole fraction of $\mathrm{H}_{2} \mathrm{~S}$ ranges up to 0.25 , which highlights the fact that eruptions with large sulfur yields do not imply excessively high sulfur contents in the fluid [Gerlach et al., 1996]. Similarly, restored whole rock S contents hardly exceed 1 wt \%. Calculated fluid/melt sulfur partition coefficients range from 50 up to 2612 (Table 1), magmas with low-silica residual melts $(<70 \mathrm{wt} \%$ $\mathrm{SiO}_{2}$ ) having the lowest partition coefficients, around 100 , and those with highly silicic melts having partition coefficients higher than 600 (Table 1). This is a direct reflection of the higher sulfur solubilities of the less fractionated liquids (Table 1). Admittedly, either when $\mathrm{XH}_{2} \mathrm{O}$ is not known (Redoubt) or when the $\mathrm{CO}_{2} / \mathrm{SO}_{2}$ ratio has not been measured ( $\mathrm{El}$ Chichón), the results obtained from such calculations are subject to rather large uncertainties. For instance, taking an $\mathrm{XH}_{2} \mathrm{O}$ of 0.95 for the Redoubt magma (instead of 0.6 ), decreases the $\mathrm{S}$ partition coefficients down to 35 and 460 for the low and high melt sulfur contents, respectively (Table 1). Similarly, taking $\mathrm{CO}_{2} / \mathrm{SO}_{2}=1$ for $\mathrm{El}$ Chichón, instead of 7 , decreases the fluid amount to $8.5 \mathrm{wt} \%$ and raises the $\mathrm{S}$ partition coefficient to 200. This shows nevertheless that our procedure gives the correct order of magnitude of S partition coefficients and that variations within reasonable ranges of the input parameters affect by a factor of 6 , at best, the calculated values. All these erupted magmas have a redox state that ranges from moderately to strongly oxidized, that is, from 1 to $2 \log$ units above the
$\mathrm{Ni}-\mathrm{NiO}$ solid buffer (NNO+1 to NNO+2). Three of them have anhydrite phenocrysts (Pinatubo [Bernard et al., 1991], El Chichón [Luhr et al., 1984], and Nevado del Ruiz [Fournelle, 1990]), a mineral diagnostic of both oxidizing and sulfur-rich conditions [Carroll and Rutherford, 1987; Luhr, 1990]. In contrast, this phase is lacking from St. Helens and Redoubt eruptions despite similar bulk rock compositions and redox state, and only pyrrhotite has been reported. Although within this redox range no systematic relationship between $\mathrm{fO}_{2}$ and sulfur partition coefficients emerges, these data clearly suggest that, under oxidizing conditions $\left(\mathrm{O}_{2}>\mathrm{NNO}+1\right)$, sulfur in silicic to intermediate arc magmas is strongly partitioned into the fluid phase relative to the melt. However, no eruption of silicic magma with $f \mathrm{O}_{2}<\mathrm{NNO}+1$ has been monitored for its sulfur yield. Consequently, it remains to be determined whether the elevated partition coefficients observed under oxidized conditions equally apply under more reduced redox states.

\section{Experimental Constraints on Sulfur Partitioning}

\subsection{Experimental and Analytical Techniques}

The experimental and analytical techniques are as by Scaillet and Evans [1998] and only the salient features will be recalled here. We have performed phase equilibrium experiments on a natural sample of the white dacitic pumice ejected during the June 15, 1991, eruption of Mount Pinatubo [Bernard et al., 1991; Pallister et al., 1992, 1996]. This dacite has been used in various experimental programs designed primarily at fixing constraints on preeruption conditions of this major volcanic event of this century [Rutherford and Devine, 1996; Evans and Scaillet, 1997; Scaillet and Evans, 1998]. In the present study, oxygen fugacity $\left(\mathrm{O}_{2}\right)$ was chosen as a master variable because it exerts a major control on the sulfur behaviour in silicate melts [Carroll and Rutherford, 1987, 1988; Luhr, 1990]. The experiments were performed either in internally heated or in cold seal pressure vessels equiped with $\mathrm{H}_{2}$ membranes for $\mathrm{fH}_{2}$ control [Scaillet et al., 1992; Schmidt et al., 1995]. Pressures and temperatures are known to within $\pm 2 \mathrm{MPa}$ and $\pm 5^{\circ} \mathrm{C}$, respectively. Run durations varied between 191 and 502 hours, depending on temperature. Starting materials were dry glasses obtained by fusing twice at 1 bar (in air at $1400^{\circ} \mathrm{C}$ ) a white pumice from Mount Pinatubo; the only exception, run 75 , was done with a gel of rhyolitic composition. Au capsules were used with distilled and demineralized water, and elemental sulfur was added using a high-precision balance $( \pm 0.001 \mathrm{mg})$. All runs contained an $\mathrm{H}-\mathrm{S}-\mathrm{O}$ fluid phase but run 53 that also contained $\mathrm{CO}_{2}$ added as silver oxalate with an initial $\mathrm{H}_{2} \mathrm{O}$ molar fraction of $0.9\left(\mathrm{H}_{2} \mathrm{O} /\left(\mathrm{H}_{2} \mathrm{O}+\mathrm{CO}_{2}\right)\right)$. The oxygen fugacity is calculated knowing $\mathrm{fH}_{2}$ from the membrane and assuming $\mathrm{XH}_{2} \mathrm{O}=1$ and is tabulated relative to the $\mathrm{NNO}$ buffer $\left(\triangle \mathrm{NNO}=\log f \mathrm{O}_{2}\right.$ experiment $\left.-\log f \mathrm{O}_{2} \mathrm{NNO}\right)$ taken at the experimental pressure and temperature. Maximum uncertainty in $f \mathrm{O}_{2}$ is \pm 0.2 unit log.

Run products were characterized by electron microprobe, SEM, and Xray diffraction techniques. Phase proportions were obtained from a constrained least squares mass balance procedure that propagates analytical errors [Albarède, 1995]. The calculations use the concentrations in $\mathrm{SiO}_{2}, \mathrm{Al}_{2} \mathrm{O}_{3}$, FeOtot, $\mathrm{MgO}, \mathrm{CaO}, \mathrm{Na}_{2} \mathrm{O}, \mathrm{K}_{2} \mathrm{O}$, and $\mathrm{TiO}_{2}$, as obtained from microprobe analyses and includes all condensed phases (melt + 
crystals). The pyrrhotite ( $\mathrm{FeS})$ and anhydrite $\left(\mathrm{CaSO}_{4}\right)$ weight proportions derived in this way depend on the determination of $\mathrm{FeO}$ and $\mathrm{CaO}$ content and are known to $\pm 15 \%$. The accuracy of this method was tested by performing an experiment on a rhyolitic composition at $930^{\circ} \mathrm{C}, 220 \mathrm{MPa}$, with no fluid phase (i.e., with less water than that needed for saturation) which crystallized only pyrrhotite [Clemente et al., 1997]. Knowing the phase proportions (determined by mass balance) and the sulfur content of all sulfur-bearing phases ( $S$ content of glass measured by electron microprobe, a stoechiometric $\mathrm{S}$ content for both pyrrhotite and anhydrite), the bulk $S$ content of the charge was calculated and found to agree to within $\pm 5 \mathrm{wt} \%$ of the amount of sulfur added to the charge. For anhydrite-bearing charges listed in Table 2, the abundance of the fluid phase (fluid) and its equilibrium composition (in particular its sulfur content, $S_{\text {fluid }}$ ) are calculated from the phase abundances and the melt water contents (determined using the by-difference method [Devine et al., 1995]), and knowing the masses of water, glass powder, and sulfur added to the charge. For pyrrhotite-bearing charges, such a procedure yielded sulfur contents in the fluid phase close to zero. For these charges, the sulfur content of the fluid was also calculated from the thermodynamic modeling of the fluid phase speciation knowing both $f \mathrm{H}_{2}$ and $f \mathrm{~S}_{2}$. The sulfur fugacity $\left(\mathrm{S}_{2}\right)$ is calculated from the pyrrhotite composition [Toulmin and Barton, 1964] as obtained from Xray diffraction of pyrrhotite bearing-run products, except in charges $42 \mathrm{~b}$ and 75 , where pyrrhotite modal abundance is too low for the use of Xray diffraction. Melt sulfur contents $\left(S_{\text {melt }}\right)$ were obtained from electron microprobe analyses with the following analytical conditions: accelerating voltage of $15 \mathrm{kV}$, sample current of 50 $\mathrm{nA}$, counting time of $180 \mathrm{~s}$ and focused beam, which ensure an $S$ detection limit of $40 \mathrm{ppm}$. In all mass balance calculations, the dominant sulfur-bearing species in the fluid phase is taken as $\mathrm{H}_{2} \mathrm{~S}$ for $\mathrm{fO}_{2}$ lower than $\mathrm{NNO}+2$, and as $\mathrm{SO}_{2}$ for higher $f \mathrm{O}_{2}$. The fluid /melt sulfur partitioning $\left(\mathrm{S}_{\text {fluid }} / \mathrm{S}_{\text {melt }}\right)$ is calculated with $S_{\text {fluid }}$ obtained from mass balance calculations in anhydrite-bearing charges and $S_{\text {fluid }}$ obtained from thermodynamic modeling in pyrrhotite-bearing charges. Uncertainties in phase proportions translate into $10 \%$ uncertainty for the partition coefficients for anhydrite-bearing charges. For pyrrhotite-bearing ones, uncertainty due to experimental error in both $\mathrm{fH}_{2}$ and $\mathrm{fS}_{2}$ is less than $5 \%$. Repeated checks for the presence of sulfur in the capsule walls proved always negative (at a detection level of $70 \mathrm{ppm}$ ).

\subsection{Results}

The results and the experimental conditions explored are listed in Table 2. All charges contained either pyrrhotite, at $\mathrm{fO}_{2}$ from $\mathrm{NNO}$ to $\mathrm{NNO}+1$, or anhydrite for $\mathrm{fO}_{2}$ higher than $\mathrm{NNO}+2$, or both phases at intermediate $\mathrm{O}_{2}$, in agreement with previous experimental studies [Carroll and Rutherford, 1987, 1988; Luhr, 1990]. The dependence of the sulfur partitioning relative to the $\mathrm{OO}_{2}$ is shown on Figure 1 for all conditions of $P$, $T$, and fluid phase compositions (with $\mathrm{CO}_{2}$-bearing and $\mathrm{CO}_{2}$ free) investigated. Clearly, sulfur partitioning depends strongly on redox conditions. At $780^{\circ} \mathrm{C}$, it is close to 1 for $f \mathrm{O}_{2}$ below $\mathrm{NNO}+1$ and around $10^{3}$ at higher $\mathrm{O}_{2}$. In contrast with sulfur speciation, however, where the relative proportions of reduced and oxidized species in both the fluid and melt phases change continuously with changing $\mathrm{OO}_{2}$ (Figures $1 \mathrm{~b}-1 \mathrm{c}$ ), the sulfur partition coefficient displays an abrupt increase as $f \mathrm{O}_{2}$ increases, with no clear intermediate steps between the reduced and oxidized domains (Figure 1a) and remains flat in both domains on either side of a boundary separating anhydrite-free (i.e., only pyrrhotite is present) from anhydrite-bearing liquids. This behavior suggests that the change in the sulfur partition coefficient is not solely due to a shift from a soluble species of

Table 2. Experimental Fluid/Melt Partition Coefficients for Sulfur

\begin{tabular}{|c|c|c|c|c|c|c|c|c|c|c|c|c|}
\hline & $\begin{array}{c}P \\
\mathrm{MPa} \\
\end{array}$ & $\begin{array}{l}T \\
{ }^{\circ} \mathrm{C} \\
\end{array}$ & $\begin{array}{c}\triangle N N O,{ }^{a} \\
\text { bars }\end{array}$ & $\begin{array}{c}\log f_{2}, \\
\text { bars }\end{array}$ & $\begin{array}{l}\mathrm{XH}_{2} \mathrm{O},{ }^{\mathrm{b}} \\
\text { (in Fluid) }\end{array}$ & $\begin{array}{c}\text { Fluid, } \\
\text { wt } \%\end{array}$ & $\begin{array}{l}\mathrm{SıO}_{2},{ }^{d} \\
\text { wt \% }\end{array}$ & $\begin{array}{c}\text { Bulk S, } \\
\text { wt } \%\end{array}$ & $\begin{array}{c}\text { S Melt, } \\
\text { ppm }\end{array}$ & $\begin{array}{l}\text { Anh, } \mathrm{g} \\
\text { wt } \%\end{array}$ & $\begin{array}{l}\text { Po, } \\
\text { wt } \%\end{array}$ & $\mathrm{~S}_{\text {fluid }} / \mathrm{S}_{\text {meit }}$ \\
\hline $17^{\mathrm{h}}$ & 224 & 776 & -0.01 & -306 & 1.0 & 9.2 & 75.9 & 1.20 & $65(41)$ & - & 3.3 & 1 \\
\hline $19^{h}$ & 224 & 776 & 1.04 & -1.17 & 10 & 7.9 & 762 & 110 & $44(18)$ & - & 3.4 & 6 \\
\hline 21 & 225 & 776 & 171 & - & 099 & 9.8 & 77.1 & 1.04 & $111(12)$ & 0.7 & - & 689 \\
\hline $42 b$ & 225 & 899 & 1.20 & - & 0.99 & 65 & 688 & 100 & $594(24)$ & 0.6 & 20 & 72 \\
\hline 52 & 224 & 781 & 227 & - & 0.95 & 93 & 75.4 & 0.95 & $141(35)$ & 0.9 & - & 691 \\
\hline $53^{i}$ & 224 & 781 & 2.27 & - & 0.81 & 11.9 & 776 & 102 & $83(10)$ & 12 & - & 921 \\
\hline 58 & 224 & 781 & 2.27 & - & 092 & 1.9 & 76.6 & 0.32 & $95(15)$ & 0.4 & . & 1564 \\
\hline 69 & 398 & 780 & 263 & - & 0.93 & 83 & 74.6 & 135 & $176(13)$ & 2.4 & - & 729 \\
\hline $75^{j}$ & 217 & 778 & 1.40 & - & 0.99 & 6.3 & 792 & 112 & $100(15)$ & 02 & 07 & 1310 \\
\hline
\end{tabular}

${ }^{\mathrm{a}} \Delta \mathrm{NNO}=\log \mathrm{O}_{2}$ experiment $-\log f \mathrm{O}_{2} \mathrm{NNO}$

$\mathrm{b}_{\mathrm{Mole}}$ fraction of $\mathrm{H}_{2} \mathrm{O}$ in the fluid at the experimental $P$ and $T$, calculated from mass balance.

${ }^{C}$ Weight percent of fluid in the charge at the experımental $P$ and $T$.

${ }^{d}$ Silica content of the experimental residual glasses reported on an anhydrous basis.

${ }^{e}$ Bulk $S$ content added to the charge.

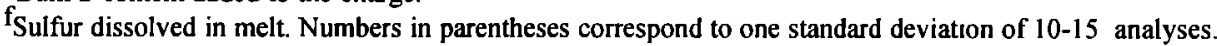

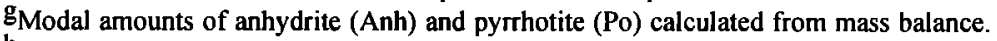

${ }^{h}$ The sulfur partition coefficient reported is that obtained using the fluid phase composition calculated from thermodynamic modeling.

${ }^{\mathrm{i}}$ Run done with a starting fluid phase having a mole fraction of $\mathrm{H}_{2} \mathrm{O} /\left(\mathrm{H}_{2} \mathrm{O}+\mathrm{CO}_{2}\right)=0.9$.

J Run done with a synthetic glass of rhyolitic composition. 

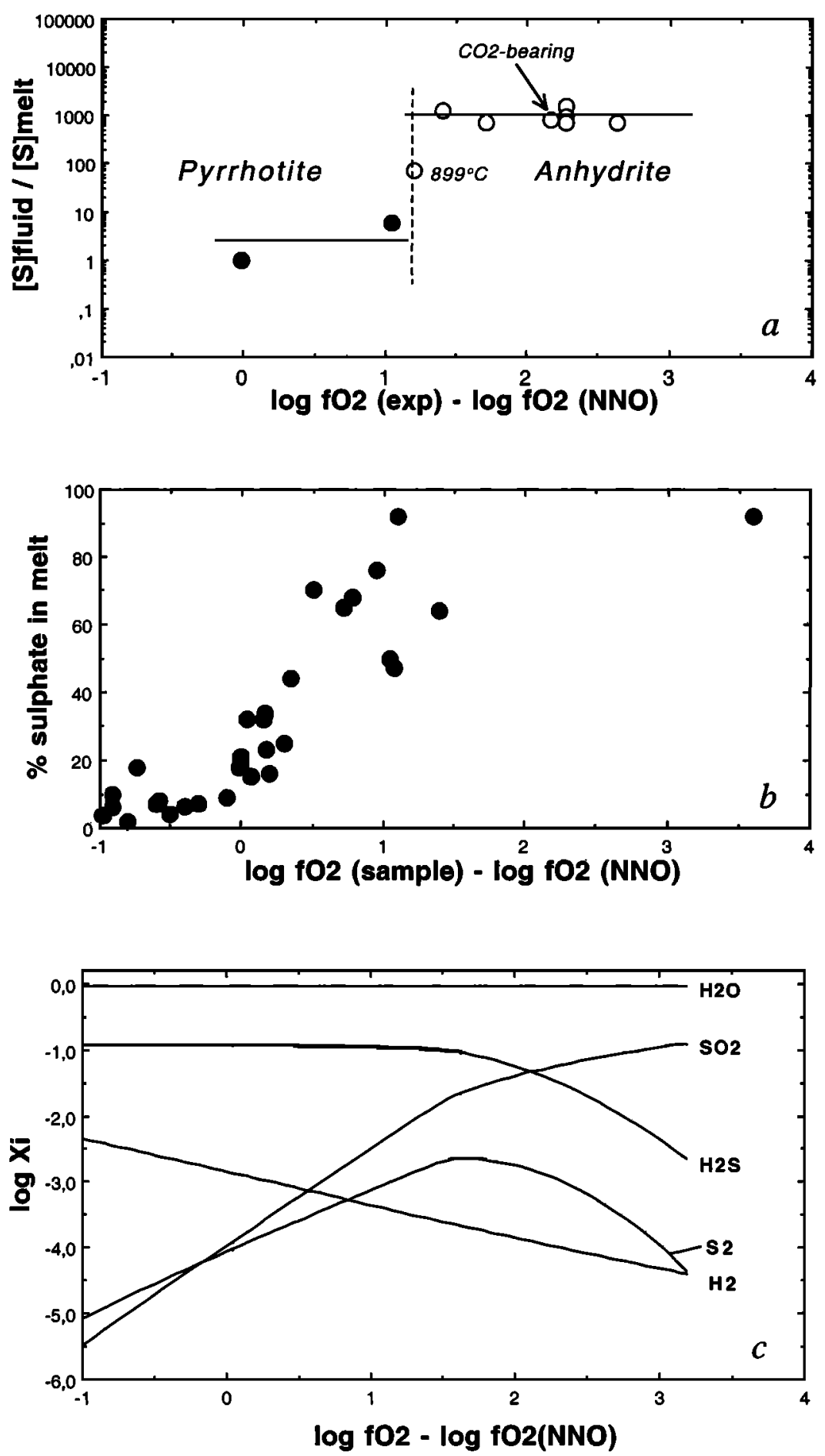

Figure 1. Effect of $\mathrm{fO}_{2}$ on (a) the fluid/melt partition coefficient of sulfur, (b) the sulfur speciation in silicate glasses, and (c) fluid speciation in the H-O-S system. Uncertainty of the partition coefficients is equivalent to, or smaller than, the symbol sizes. In Figure 1a, the vertical dashed line separates the field of pyrrhotite-bearing liquids (solid symbol) from that of anhydrite-bearing liquids (open symbols). The melt sulfur speciation is for available natural or experimental basaltic to dacitic glass compositions [Carroll and Rutherford, 1988; Nilsson and Peach, 1993; Wallace and Carmichael, 1994; Metrich and Clochiatti, 1996] because the very low amounts of sulfur dissolved in most of our experimental melts do not allow estimates of their sulphate/sulphide ratio by the peakshift method [Carroll and Rutherford, 1988]. The fluid phase speciation, reported here in terms of the $\log$ of the mole fraction of each species $\left(\log \mathrm{X}_{\mathrm{i}}\right)$, has been calculated in the system H-O-S using a modified Redlich-Kwong equation of state [Holloway, 1977] at a total pressure of $220 \mathrm{MPa}$, a temperature of $780^{\circ} \mathrm{C}$ and for $\mathrm{aH}_{2} \mathrm{O}=0.9$, which are conditions similar to those of most of the experiments listed in Table 2. 
sulfur to a less soluble one arising from an increase of $\mathrm{O}_{2}$ but is also related to a discontinuous reaction such as a mineral crystallization. Indeed, the critical factor is the presence of anhydrite, which crystallized in all charges above NNO+1. Pyrrhotite-bearing magmas coexisting with anhydrite have similar partition coefficients to those crystallizing only anhydrite. A pressure increase of nearly $200 \mathrm{MPa}$ has no detectable effect on the sulfur partitioning when anhydrite is present. In the same way, the presence of $\mathrm{CO}_{2}$ in the fluid phase does not affect the partitioning, at least in the low-pressure range investigated (Table 2). In contrast, the experiment performed at $900^{\circ} \mathrm{C}$ has a partition coefficient that is 10 times lower than those obtained at around $780^{\circ} \mathrm{C}$. This goes along with a melt composition significantly poorer in $\mathrm{SiO}_{2}(68.8 \mathrm{wt}$ $\%)$ relative to those obtained at $780^{\circ} \mathrm{C}(75-79 \mathrm{wt} \%)$ and a higher sulfur solubility in the melt. The sulfur partition coefficients derived from the study of volcanic eruptions and those obtained from the experiments done at $\mathrm{fO}_{2}$ higher than $\mathrm{NNO}+1$ compare well to each other (Figure 2). This strongly suggests that the erupted magmas were fluid-saturated at depth and that equilibrium in sulfur partitioning between melt and fluid was achieved before eruption. At $\mathrm{fO}_{2} \geq \mathrm{NNO}+1$, the sulfur partitioning in intermediate to silicic magmas is also dependent on melt composition, expressed for convenience in Figure 2 as the melt $\mathrm{SiO}_{2}$ content. Both natural and experimental data indicate that melts with a silica content higher than $70 \mathrm{wt} \%$ display a nearly tenfold increase in sulfur partitioning relative to those with $\mathrm{SiO}_{2}<70 \mathrm{wt} \%$. Partition coefficients obtained for all anhydrite-bearing charges with melt silica contents in the range 74-79 wt \% average 984, while that for a melt $\mathrm{SiO}_{2}$ of $69 \mathrm{wt} \%$ is 72 .

In contrast, charges held at an $\mathrm{fO}_{2}$ below $\mathrm{NNO}+1$ crystallized only pyrrhotite and yielded extremely low partition coefficients (Table 2) with pyrrhotite proportions nearly balancing the amount of added sulfur (note that this confirms that sulfur loss toward the capsule walls, if any, was minor). Thermodynamic calculations of the fluid phase indicate that the fluid phase is nearly pure water in anhydrite-free charges, in agreement with the mass balance constraints (Table
2). For example, the calculated fluid phase speciation in charge 17 is $\mathrm{XH}_{2} \mathrm{O}=0.99322, \mathrm{XH}_{2}=0.00125$, and $\mathrm{XH}_{2} \mathrm{~S}=0.00553$, which corresponds to an $\mathrm{S}$ content of the fluid of $86 \mathrm{ppm}$ and thus a partition coefficient of 1.3. For the charge 19, the calculated partition coefficient is 6 , the fluid having only 245 ppm of sulfur. These facts indicate that nearly all the sulfur is locked into pyrrhotite with correspondingly low amounts of sulfur partitioned into the melt and fluid phases. Thus, at bulk sulfur contents of $1 \mathrm{wt} \%$, almost no sulfur is present in the fluid phase under reduced conditions, even for magmas having silica-rich and iron-poor residual melts (Table 2).

Such a contrasted behavior may appear in contradiction with the enhanced sulfur solubility in hydrous silicate melt under oxidizing condition [Carroll and Rutherford, 1987, 1988; Luhr, 1990]. On the basis of the melt-solubility trend, one could predict a coexisting fluid phase poorer in sulfur under oxidizing conditions than under reduced ones. Our results demonstrate the opposite trend, however. This stems from the facts that (1) anhydrite contains less sulfur (24 wt \%) than pyrrhotite (37 wt \%) and (2), at comparable levels of bulk sulfur contents, it crystallizes in lower abundances than does pyrrhotite, typically in weight proportions 3 to 10 times lower (Table 2). Both factors act in concert so there is much more sulfur left over for the fluid phase under oxidizing than under reducing conditions, especially at low temperatures where sulfur solubilities of silicate melts are low. For example, the total sulfur content of the fluid phase in charge 21 (NNO+1.71) is $7.65 \mathrm{wt} \%$ whereas it is only $0.0245 \mathrm{wt} \%$ in charge 19 $(\mathrm{NNO}+1.04)$. The difference is of more than 2 orders of magnitude despite the fact that these two charges differ only by $\sim 0.7 \mathrm{log}$ units in $\mathrm{fO}_{2}$. Anhydrite crystallizes in lower abundances than pyrrhotite because it competes for $\mathrm{Ca}$ with other calcic phases, among which plagioclase and hornblende are the most important. Consequently, crystallization of abundant anhydrite (i.e., $>3 \mathrm{wt} \%$, Table 2 ) is not expected in melts saturated in plagioclase and/or hornblende, a very common phase assemblage in intermediate to silicic arc magmas at rest in upper crustal levels [e.g., Bernard et al., 1991; Sisson and Grove, 1993]. On the other hand, the strong

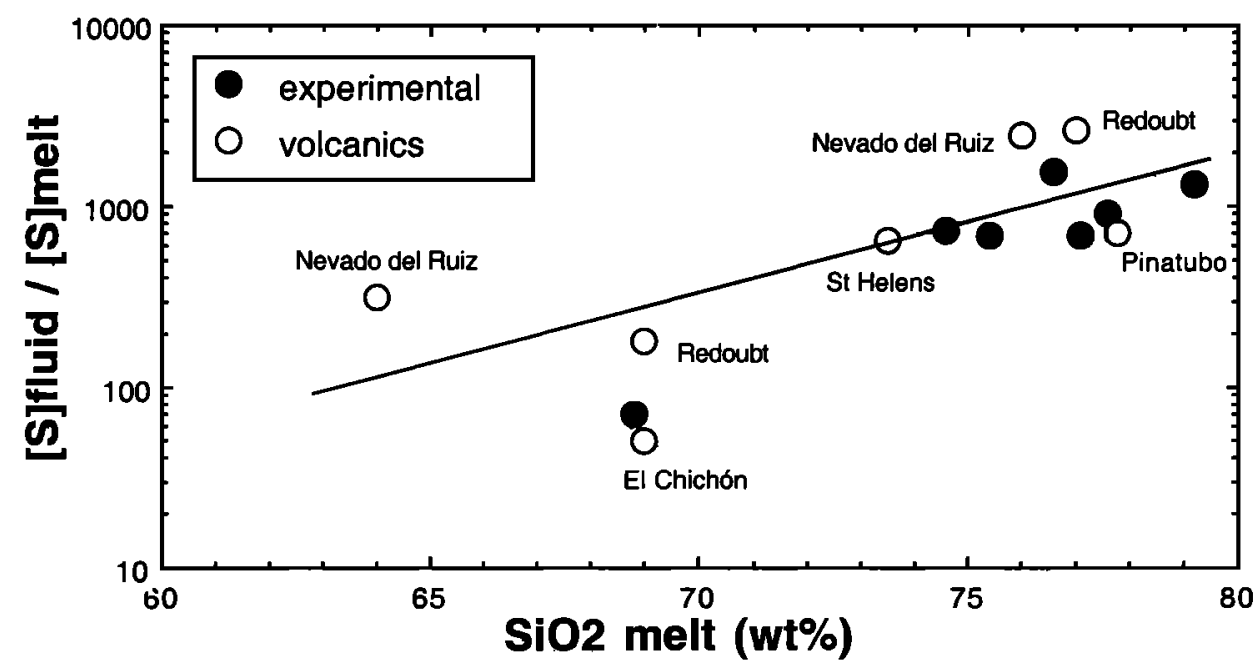

Figure 2. Natural and experimental sulfur partition coefficients plotted against the residual melt silica content (anhydrous basis). The two values of partition coefficients for the Redoubt and Nevado del Ruiz eruptions correspond to the lowest and highest sulfur contents analyzed in melt inclusions [Gerlach et al., 1994; Sigurdsson et al., 1990]. 
siderophile character of sulfur under low $\mathrm{fO}_{2}$ is well known [Haughton et al., 1974]. Pyrrhotite (or an immiscible sulfide liquid) will also compete with ferromagnesian phases such as hornblende, but these would readjust their compositions by becoming increasingly Mg-rich [Tracy and Robinson, 1988; Scaillet and Evans, 1998]. In fact, at low $\mathrm{fO}_{2}$, as long as there is enough iron in the melt, increasing the amount of sulfur in the system will chiefly produce more pyrrhotite and any coexisting fluid phase will contain only trivial amounts of sulfur. Thus the modal amount of pyrrhotite of reduced silicic magmas probably faithfully reflects the total amount of sulfur present in the system. Such behavior can be probably extended to more mafic compositions since it has been shown that an increase in iron content increases sulfur solubility at low $\mathrm{fO}_{2}$ $(<\mathrm{NNO})$ [Haughton et al., 1974]. These results also show that the reduction of an oxidized and volatile-bearing sulfur-rich silicic magma will not increase the sulfur content of the volatile phase, such as proposed for the Pinatubo eruption by Kress [1997]. Instead, the decrease in melt sulfur solubility that accompanies the decrease in $\mathrm{fO}_{2}$ will only lead to pyrrhotite crystallization, as anhydrite breakdown will do.

Therefore, unless the bulk sulfur content largely exceeds the buffering capacity of the melt (i.e., its iron budget), it appears that the escape of a fluid phase coexisting with a reduced sulfur-bearing silicic melt will not release significant amounts of sulfur to the atmosphere. If sulfur outgassing is to take place, it can only be due either to pyrrhotite breakdown, in a way similar to that proposed for anhydrite [Devine et al., 1984; Rutherford and Devine, 1996], or to the exsolution of sulfur dissolved in the melt. The extent to which both processes can supply sulfur to the gas phase is controlled by their kinetics. However, as for anhydrite, pyrrhotite breakdown is unlikely to operate on the timescale typical of Plinian eruptions [Westrich and Gerlach, 1992], in keeping with the lack of clear textural evidence for such a mechanism. In this respect, the good agreement observed between our experimentally derived $S$ partition coefficients and those obtained by studying volcanic clouds associated to the eruption of anhydrite-bearing magmas (Pinatubo, El Chichón) suggests that anhydrite breakdown contributes little to the sulfur budget emitted to the atmosphere during explosive eruptions of acid magmas. The rate of sulfur exsolution (in this work the term exsolution refers to the volatile degassing that occurs during the eruptive event) depends on the sulfur diffusivity in the melt, which has been shown to be exceedingly low in hydrous rhyolitic melts [Baker and Rutherford, 1996]. The latter is testified to by the fact that matrix glasses of silicic magmas are often weakly degassed with respect to sulfur [Devine et al., 1984] even in slowly cooled, dome forming, silicic systems such as the Inyo Domes [Westrich et al., 1988]. Given that the bulk sulfur contents used in this study are likely to represent maximum values, we thus conclude that in silicic magmas or in largely crystallized mafic magmas involved in explosive eruptions, extensive sulfur output is not anticipated under reduced conditions (i.e., for $f \mathrm{O}_{2}$ at or below $\mathrm{NNO}+1$ ) even if they coexist with a fluid phase. Such a mechanism of sulfur release is probably efficient only in anhydrite-bearing, fluid-saturated magmas. By implication, this shows that sulfur-rich volcanic clouds associated with silicic volcanism do not result from the enhanced sulfur solubility of silicate melts under oxidizing conditions but to the coexistence of a fluid phase at depth. It should not be concluded, however, that only anhydritebearing magmas are prone to extensive sulfur degassing. It is well known that reduced magmas can release large quantities of sulfur to the atmosphere [e.g., Moore and Fabi, 1971; Gerlach, 1986; Métrich et al., 1991]. This demonstrates that sulfur outgassing in magmas is not uniquely controlled by their redox state. However reduced magmas having the potential to release large quantities of sulfur are mostly basaltic in composition and it has been shown that as the melt composition becomes more mafic, the disagreement between the petrological and remote-sensing estimates diminishes [Self and King, 1996]. In mafic melts, melt viscosity and sulfur diffusity are clearly low enough to allow sulfur loss via exsolution from the melt phase before it quenches to glass.

\section{Sulfur Yield in Past Volcanic Eruptions}

Our experimental results allow us to reassess the sulfur output associated with past silicic explosive eruptions for which the redox state, melt sulfur content, and mass of erupted magma are known. The major unknown still outstanding is the possibility that the magma was fluid-saturated before eruption. Although the amount of free volatiles under preeruption conditions can be estimated [Wallace et al., 1995], the necessary data for such calculations are not yet available for most volcanic eruptions. Therefore, in the following, most calculations were done assuming that the magma coexisted at depth with $1 \mathrm{wt} \%$ of fluid phase, which is at the low end of the range inferred for volcanic eruptions [Wallace et al., 1995]. Only major and petrologically well-characterized eruptive events were taken into account: the Taupo, Tambora, Krakatau, Katmai, and Santa María eruptions with ejected dense rock equivalent (DRE) volumes of magma ranging between 50 and $8.5 \mathrm{~km}^{3}$ (Table 3), and the Toba event, the major Quaternary volcanic eruption, which produced more than $2800 \mathrm{~km}^{3} \mathrm{DRE}$ of magma [Chesner et al., 1991]. For some of these eruptions, there have been suggestions as to the possible existence of a separate fluid phase in the magma chamber before eruption (e.g., Katmai [Westrich et al., 1991], Krakatau [Mandeville et al., 1996], Toba [Beddoe-Stephens et al., 1983]), which stresses the need for an evaluation of the role of this fluid phase in the sulfur output due to volcanic activity. In addition, two more ancient, but petrologically well known, eruptions were also considered: The Bishop (0.74 Ma) and Fish Canyon (27.8 Ma) tuffs in the western United States with estimated erupted volumes of magma of 600 and $3000 \mathrm{~km}^{3}$ (DRE), respectively . The latter eruptive event is one of the largest ignimbrite deposit so far recognized.

The Santa Maria, Toba, Tambora, Katmai, Taupo, and Bishop eruptions all display a redox state at or below NNO+1 (Table 3 and see below). Therefore the fluid/melt partition coefficient of sulfur $(D)$ is taken to be 1 . For the Krakatau, $D=72$, because preeruption conditions (temperature, $\mathrm{fO}_{2}$, and liquid composition [see Mandeville et al., 1996]) are close to experimental conditions of the run $42 \mathrm{~b}$, listed in Table 2 . For the Fish Canyon tuff, we took $D=720$, because preeruption conditions are similar to those of the 1991 Pinatubo eruption. As stated above, the sulfur yield of the fluid phase is calculated assuming $1 \mathrm{wt} \%$ fluid phase in the magma chamber, including for zoned magma chambers (Katmai and Krakatau), except for the Bishop tuff, where it is taken as $5.7 \mathrm{wt} \%$ [Wallace et al., 1995]. Sulfur released from melt degassing reported in Table 3 correspond to published petrologic estimates for the Santa María, Krakatau, Katmai, Taupo, and Tambora events [Devine et al., 1984; Palais and Sigurdsson, 1989; Westrich et al., 
Table 3. Sulfur Yields for Major Volcanic Eruptions of Silicic to Intermediate Magmas

\begin{tabular}{|c|c|c|c|c|c|c|c|c|c|}
\hline $\begin{array}{r}\mathrm{V} \\
\text { Erup } \\
\mathrm{D}\end{array}$ & $\begin{array}{l}\text { Volume of } \\
\text { apted Magma } \\
\text { DRE, } \mathrm{km}^{3}\end{array}$ & $\begin{array}{l}T, \\
{ }^{\circ} \mathrm{C}\end{array}$ & $\begin{array}{c}\mathrm{NO}_{2} \\
(\Delta \mathrm{NNO})\end{array}$ & $\begin{array}{l}\mathrm{SiO}_{2} \\
\text { Melt, } \\
\text { wt \% }\end{array}$ & $\begin{array}{c}\mathrm{S} \\
\text { Melt, } \\
\mathrm{ppm}\end{array}$ & $\begin{array}{c}\text { S } \\
\text { Fluid, } \\
\text { ppm }\end{array}$ & $\begin{array}{l}\text { S Yield } \\
\text { Fluid, } \\
\text { g }\end{array}$ & $\begin{array}{c}\text { S Yield } \\
\text { Melt, } \\
\text { g }\end{array}$ & $\begin{array}{c}\text { S Yield } \\
\text { IC/OD, }^{a} \\
\text { g }\end{array}$ \\
\hline $\begin{array}{l}\text { Santa María }{ }^{b} \\
1902\end{array}$ & 8.5 & 833 & NNO-0.5 & 74 & 198 & 198 & $4.0 \times 10^{10}$ & $1.8 \times 10^{12}$ & $0.65-1.1 \times 10^{13}$ \\
\hline $\begin{array}{l}\text { Krakatau } \\
1883\end{array}$ & 12.5 & 885 & $\mathrm{NNO}+1.3$ & 72 & 200 & 14400 & $4.2 \times 10^{12}$ & $2.8 \times 10^{12}$ & $0.98-1.8 \times 10^{13}$ \\
\hline $\begin{array}{l}\text { Katmai }{ }^{c} \\
1912\end{array}$ & 15 & 800 & $<\mathrm{NNO}+1$ & 78 & 65 & 65 & $3.3 \times 10^{10}$ & $9.8 \times 10^{11}$ & $0.65-1 \times 10^{13}$ \\
\hline $\begin{array}{l}\text { Taupo }^{d} \\
177 \text { A.D. }\end{array}$ & $>35$ & $800-850$ & NNO & 76 & 44 & 44 & $3.5 \times 10^{10}$ & $1.0 \times 10^{11}$ & $6.5 \times 10^{12}$ \\
\hline $\begin{array}{l}\text { Tambora } \\
1815\end{array}$ & 50 & $>900$ & $<\mathrm{NNO}(?)$ & 59 & 381 & 381 & $5.0 \times 10^{11}$ & $9.8 \times 10^{13}$ & $2.8-6.5 \times 10^{13}$ \\
\hline $\begin{array}{l}\text { Toba } \\
74,000\end{array}$ & 2800 & $<800$ & $<\mathrm{NNO}+1$ & 77 & 80 & 80 & $5.4 \times 10^{12}$ & $3.0 \times 10^{13}$ & $0.7-1.4 \times 10^{15}$ \\
\hline $\begin{array}{l}\text { Bishop } \\
600,000\end{array}$ & 600 & $720-780$ & $<\mathrm{NNO}+1$ & 77 & 100 & 100 & $8.2 \times 10^{12}$ & $4.3 \times 10^{9}$ & - \\
\hline $\begin{array}{l}\text { Fish Canyon } \\
21.8 \mathrm{Ma}\end{array}$ & 3000 & 760 & $\mathrm{NNO}+2$ & 77 & 80 & 57600 & $4.0 \times 10^{15}$ & $7.2 \times 10^{13}$ & - \\
\hline $\begin{array}{l}\text { Pinatubo } \\
1991\end{array}$ & 5 & $750-780$ & $\mathrm{NNO}+1.7$ & 77 & 75 & 54000 & $1.0 \times 10^{13}$ & 0 & $1.0 \times 10^{13}$ \\
\hline
\end{tabular}

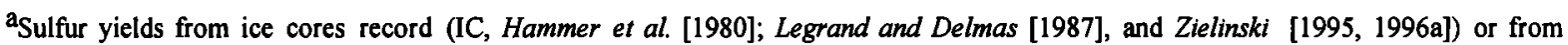
optical depth measurement (OD, Rampino et al. [1988]), except for the Pinatubo eruption whose sulfur yield comes from TOMS data [Bluth et al., 1994]. For the Bishop, and Fish Canyon eruptions, IC data are not available.

${ }^{\mathrm{b}}$ Temperature and $\mathrm{fO}_{2}$ were obtained from Fe-Ti oxide compositions (W. Rose, personal communication, 1997) and the Ghiorso and Sack [1991] solution model.

'Preeruption temperatures and concentrations of sulfur in the fluid phase are those corresponding to the rhyodacitic (Krakatau) and rhyolitic (Katmai) terms of the erupted sequence. The sulfur contributions from more mafic terms are also included in the sulfur yield of the fluid phase.

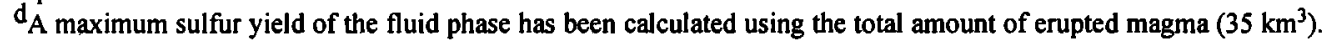

1991; Mandeville et al., 1996]. For Tambora it has been corrected by taking into account the revised volume of erupted magma [Self et al., 1984]. For the Bishop Tuff, the sulfur yield arising from melt degassing has been calculated using an average crystallinity of $15 \%$ [Hildreth, 1979], a preeruptive melt sulfur content of $100 \mathrm{ppm}$ [Anderson et al., 1989] and a sulfur loss upon eruption of $20 \mathrm{ppm}$. Also given in Table 3 are the ranges of sulfur yields obtained from the study of several Greenland or Antarctic ice cores [Hammer et al., 1980; Legrand and Delmas, 1987; Zielinski, 1995] or from opticaldepth measurements [Rampino et al., 1988].

\subsection{Santa María, 1902}

The 1902 Santa María eruption ejected mostly dacite magma [Rose, 1987] nearly identical in bulk composition to that of the Pinatubo event. In contrast to Pinatubo, however, sulfur degassing from the melt was efficient during the eruption, $50 \%$ of sulfur dissolved in the melt being lost [Palais and Sigurdsson, 1989]. This may be explained by the higher preeruption temperature and lower silica melt content relative to Pinatubo (Table 3), both factors decreasing the melt viscosity and thus increasing sulfur diffusivity [Watson, 1994]. An additional difference is that the Santa María dacite had a preeruption $\mathrm{fO}_{2}$ more than $2 \log$ units below that of Pinatubo (Table 3). According to our data this severely limits the sulfur content in the fluid phase (Table 3 ). This is in agreement with the relatively low sulfur yield of this eruptive event as recorded by polar ice cores, when compared to the Pinatubo eruption. Relative to other eruptions examined below, the petrologic estimate of the Santa María event is of the same order of magnitude as ice-core-based measurements (Table 3). This interpretation, though, is complicated by the fact that the acid signal in the ice core may be the integrated record of Santa María and several other eruptions (Mount Pelée and Soufrière) which occurred in close succession in 1902 [Rampino and Self, 1984; Zielinski, 1995]. In addition, a sulfur contribution from basaltic magmas cannot be excluded, since injection of basalt is thought to have triggered the Santa María eruption [Rose, 1987].

\subsection{Krakatau, 1883}

For the Krakatau eruption, the sulfur stored in the fluid phase and released during the eruption, added to that released by melt degassing [Mandeville et al., 1996], gives a total sulfur yield close to that obtained through ice core data or from optical depth measurements [Hammer et al., 1980; Legrand and Delmas, 1987; Zielinski, 1995; Rampino and Self, 1984]. The small difference between the two estimates can be explained if the fluid phase mass is increased by a factor of 3 , well within the range of current determinations [Wallace et al., 1995] (Table 1). Thus at Krakatau, the presence of a separate fluid phase appears to account for the sulfur-excess problem. 


\subsection{Katmai, 1912}

For the Katmai event, mineral equilibria indicate a redox state below NNO+1 for the volumetrically dominant rhyolitic part of the erupted sequence [Hildreth, 1983], which again suggests fairly low amounts of sulfur potentially stored in the fluid, especially considering the low sulfur content of the melt (Table 3). This in turn makes it difficult to balance the sulfur deficit observed between the petrologic [Westrich et al, 1991] and ice core [Legrand and Delmas, 1987; Zielinski, 1995] methods by scaling up the fluid mass as for the Krakatau eruption, because the calculated mass of fluid would be unrealistically large. Several explanations can be put forward to account for this discrepancy. One is that the high latitude of this volcanic event artificially increased its acid signal in the Greenland ice core, relative to low-latitude eruptions of comparable explosivity, which leads to an overestimate of the aerosol loading associated to this eruption [e.g., Schnetzler et al., 1997]. In addition, this event has not been identified in Antarctic ice cores, which hampers a correct evaluation of the global stratospheric aerosol loading [Legrand and Delmas, 1987]. An other potential source of error is that our calculation assumes a constant sulfur partition coefficient for the entire erupted sequence. However, Hildreth [1983] has shown that the $\mathrm{T}-\mathrm{fO}_{2}$ trend displayed by the ejecta is oblique relative to the NNO buffer with late, hotter, and more mafic magmas (mainly dacitic) being more oxidized than the early and colder rhyolitic ones. In particular, the dacitic magma $\mathrm{fO}_{2}$ straddle the critical redox threshold found in this study to be at around NNO+1. This opens the possibility for having a higher partition coefficient, and thus a higher sulfur yield, for magmas from the deepest portion of the subvolcanic system. Considering our experimental results and the preeruption conditions recorded by the dacite, the sulfur partition coefficient for the dacite may have been similar to that of Krakatau. Using $D=72$ and assuming that $3.6 \mathrm{~km}^{3}$ DRE of dacite were ejected during Plinian phases II and III [Fierstein and Hildreth, 1992], the total sulfur yield (melt +fluid) increases to $1.7 \times 10^{12} \mathrm{~g}\left(3.3 \times 10^{12} \mathrm{~g}\right.$ with the petrologic estimate of Palais and Sigurdsson [1989], owing to the higher sulfur content of their glass inclusions relative to those analyzed byWestrich et al. [1991]), which is within a factor of 4 of that obtained from ice cores (Table 3). Considering the large errors associated with ice core estimates (Table 3 ), we conclude that at Katmai the presence of a fluid phase can probably explain the sulfur deficit previously noted [Palais and Sigurdsson, 1989]. This example illustrates the fact that the behavior of sulfur in a single volcanic event is not necessarily unique. In particular, a correct estimate of the sulfur yield associated with compositionally zoned eruptions necessitates a detailed petrologic understanding of the ejecta.

\subsection{Taupo, 177 A.D.}

The Taupo volcanic area in New Zealand has been one of the most active zones of silicic volcanism in the past 50,000 years [Wilson et al, 1995]. The most recent event, dated at around $1819 \pm 17$ years, was characterized by extremely powerful explosions (ultra-Plinian [Walker, 1980]) that exclusively ejected high-silica rhyolites. Detailed petrographic analyses of the Taupo volcanics show these to be fairly reduced magmas, with preeruption $\mathrm{fO}_{2}$ at or below NNO [Dunbar et al., 1989; Blake et al, 1992; Evans and Ghiorso, 1995]. The sulfur yield associated with this eruption, either from melt degassing
[Palais and Sigurdsson, 1989] or from fluid release, can be calculated to be low (Table 3 ). The $\mathrm{SO}_{4}{ }^{2-}$ record of the Greenland Ice Sheet Project 2 (GIPS2) ice core shows a high $\mathrm{SO}_{4}{ }^{2-}$ residual dated at 181 A.D., tentatively correlated to the Taupo event [Zielınski et al., 1994]. On this basis and taking into account the southern hemisphere location of the volcano, Zielinski [1995] calculated that the Taupo eruption could have loaded a minimum of $6.5 \times 10^{12} \mathrm{~g}$ of sulfur into the stratosphere (Table 3 ). This estimate is more than an order of magnitude higher than the petrologic one [Palais and Sigurdsson, 1989], hinting at a possible role of a fluid phase (Table 3). However, Antarctic ice cores, which are closer to the eruption site than the GIPS2, have not yet revealed any clear acid signal that could be attributed to the Taupo event [see Palais and Stgurdsson, 1989]. This suggests that the acid signal dated at 181 A.D. in the GIPS2 is not related to the Taupo eruption. Consequently, we concur with the conclusion of Palais and Sigurdsson [1989] that the Taupo event, despite its magnitude, was a sulfur-poor volcanic event.

\subsection{Bishop Tuff}

The Bishop tuff is an example of highly silicic magma for which, in contrast to all previous examples, constraints on the amount of fluid phase can be placed [Wallace et al., 1995]. As for the Taupo case, its preeruption redox state (below NNO+1 [Hildreth, 1979]) and low melt sulfur contents [Anderson et al., 1989] preclude strong partitioning of sulfur into the fluid phase, which in turn limits extensive sulfur output. Indeed, the calculated sulfur yield of this large ignimbrite-dominated deposit is lower by more than a factor of 2 relative to that of the Pinatubo eruption, yet the erupted mass is about 120 times bigger (Table 3 ). Note that assuming a complete sulfur loss on eruption increases by a factor of 5 the sulfur yield, which will not significantly increase any climatic effect related to this geological event.

\subsection{Tambora, 1815}

The strongly silica-undersaturated nature of the Tambora magma as well as its poorly constrained redox state complicates the calculation for sulfur partitioning. Nevertheless this eruption is one of the first for which a clear effect on regional to global climate systems could be established [Stothers, 1984; Harington, 1992], and we have applied our results to this event in order to see if extrapolation of the results obtained on silicic magmas to more mafic ones is warranted. We have chosen a redox state below $\mathrm{NNO}+1$ and thus a sulfur partition coefficient of 1 . Because of its rather high melt sulphur contents and the low assumed $\mathrm{fO}_{2}$, the sulfur yield associated with a fluid release is more than 2 orders of magnitude lower than that from melt degassing (Table 3) and thus contributes little to the $\mathrm{SO}_{2}$ stratospheric loading. However, in contrast with the more silicic eruptions considered above, the petrologic estimate of the Tambora eruption [Devine et al., 1984] is slighty higher than that obtained by ice core records [Hammer et al., 1980; Legrand and Delmas, 1987]. That more mafic compositions degas their sulfur more efficiently through exsolution from the melt has been already noted by previous workers [Devine et al., 1984; Self and King, 1996]. Our calculations suggest that strongly alkaline mafic magmas, such as the Tambora trachyandesite, follow the same pattern. The fact that there is no need to call upon a separate volatile phase points to a less important role for the fluid in mafic than in silicic magmas. This could be due 
to a lower amount of fluid in mafic magmas as compared to that of more silicic ones, to a lower sulfur content of the fluid, as our experimental results suggest, or to both possibilities.

\section{Toba and Fish Canyon Eruptions}

Compared to the previously discussed volcanic events, the Toba and Fish Canyon eruptions were of very large magnitude and are more likely to have induced protracted worldwide climate changes. For instance, the stratospheric aerosol loading associated with the Toba event has been recently proposed to have greatly accelerated a shift to glacial conditions [Rampino and Self, 1992]. However, the sulfur released by the Toba eruption has been estimated only by scaling up sulfur yields associated with small to moderate historical eruptive events [Rampino et al., 1985] or by using ice core data (Table 3, [Zielinski et al., 1996a]). This major volcanic event currently lacks a petrologic estimate of sulfur yield. The same remark applies to the Fish Canyon tuff. Nevertheless, in both cases, comparison of petrological characteristics of the ejecta against experimental data, as well as mineralogical equilibria, imply preeruption temperatures lower than than $800^{\circ} \mathrm{C}$, around $750-760^{\circ} \mathrm{C}$ for the Fish Canyon tuff [Johnson and Rutherford, 1989] and $700-780^{\circ} \mathrm{C}$ for the Toba magma [Beddoe-Stephens et al., 1983; Chesner, 1998]. Both are characterized by highly fractionated residual melts with $\mathrm{SiO}_{2}$ contents of $77 \mathrm{wt} \%$. Experimental data on sulfur solubility in silicate melts constrain preeruption melt sulfur contents to be lower than $100 \mathrm{ppm}$, probably between 80 and $60 \mathrm{ppm}$, similar to that displayed by the Pinatubo dacite [Westrich and Gerlach, 1992]. Thus both magmas display similar preeruption conditions except for their redox states. The preeruption redox state of the Toba magma has been recently evaluated to be close to NNO through FeTi oxides equilibria [Chesner, 1998]. Such a relatively reduced redox state is also corroborated by the occurrence of fayalite and pyrrhotite and by the high $\mathrm{Fe} / \mathrm{Mg}$ ratios of the residual melt and coexisting hornblende and biotite [Beddoe-Stephens et al., 1983; Rose and Chesner, 1987; Chesner, 1998], similar to those of (reduced) rhyolitic ash flow tuffs in the western United States (i.e., Bandelier tuffs [Warshaw and Smith, 1990]). In contrast, the Fish Canyon tuff displays a redox state similar to that of the Pinatubo dacite, between $\mathrm{NNO}+1$ and $\mathrm{NNO}+2$ [Johnson and Rutherford, 1989; Evans and Scaillet, 1997], lying within the stability field of anhydrite, though the latter mineral has not been identified, perhaps because of post-eruptive dissolution by meteoric water [e.g., $L u h r, 1991]$. Given the high silica contents of the Toba and Fish Canyon residual melts, sulfur exsolution from the melt during eruption must have been minimal, as illustrated by the Pinatubo case [Westrich and Gerlach, 1992] and eruptions of other high-silica magmas [Devine et al., 1984; Westrich et al., 1988]. Assuming that in both cases $25 \%$ of the sulfur dissolved in the melt was able to exsolve, which is probably a maximum given the low rates of sulfur diffusion in rhyolitic melts [Baker and Rutherford, 1996], the enormous mass of ejecta (assuming for both a crystallinity of 40\%, [Beddoe-Stephens et al., 1983; Chesner, 1998; Johnson and Rutherford, 1989]) makes this source of sulfur considerable, between 3 and $7 \times 10^{15} \mathrm{~g}$ (Table 3), yet it is of the same order of magnitude as the sulfur yield associated with the much smaller Pinatubo eruption [Bluth et al., 1994] (Table 3). Dramatic differences in sulfur yields arise, however, when considering the possibility of a coexisting fluid phase.
For the Toba eruption, the amount of sulfur stored in the fluid phase is one order of magnitude lower than that arising from exsolution and thus can be neglected in the sulfur budget associated with that eruption. The low sulfur content of any coexisting fluid phase in the Toba magma is also indicated by the low $\mathcal{S}_{2}$ retrieved from the pyrrhotite compositions $\left(\log f \mathrm{~S}_{2}\right.$ $=-2.7 \pm 0.2$, Chesner , [1998]), very close to that obtained in our experiment at NNO (charge 17, Table 2). In addition, the detailed petrological study carried out by Chesner [1998] yielded a gas-saturation pressure (150-200 $\mathrm{MPa}$, obtained from glass inclusion analyses) lower than total pressure (300 $\mathrm{MPa}$, obtained from the hornblende geobarometer) which suggests that the magma was not volatile-saturated. Overall, the stratospheric aerosol loading associated with the Toba eruption is one order of magnitude lower than that associated with the Tambora event, despite the fact that the latter ejected only $50 \mathrm{~km}^{3}$ of magma (DRE). In contrast, the Fish Canyon magma could have released $6 \times 10^{15} \mathrm{~g}$ of sulfur if it coexisted with $1 \mathrm{wt} \%$ fluid, a sulfur amount 2 orders of magnitude higher than the contribution arising from sulfur exsolution from the melt (Table 3). The latter sulfur yield figure is comparable to previous estimates for the Toba event, which have fallen in the range $10^{15}-10^{16} \mathrm{~g}$ [Rampino et al., 1985; Zielinski et al., 1996a], and for which catastrophic climatic effects have been predicted, such as ocean surface cooling of $2-6^{\circ} \mathrm{C}$ lasting for several years [see Rampino et al., 1988].

Our estimate of the sulfur yield associated with the Toba eruption is 2 to 3 orders of magnitude lower than previous ones [Rampino et al., 1985; Zielinski et al., 1996a]. This illustrates the hazards in scaling up sulfur yields obtained for small eruptions of magmas having redox states different from those involved in large-magnitude events. The climatic effect arising from this revised sulfuric acid aerosol loading should have been comparable to that produced by the Pinatubo eruption [Hansen et al., 1996], which resulted in a global cooling of $0.3^{\circ} \mathrm{C}$. Although the huge mass of fine dust injected into the strastosphere by the Toba event certainly strongly affected the climate, the residence time of volcanic ash in the stratosphere does not likely exceed weeks or months, although detailed modeling of ash residence times in the stratosphere for eruptions of magnitude comparable to that of Toba has not been done. An additional limitation on the potential stratospheric loading associated with this volcanic event is the possible lack of a sustained and large Plinian column during the eruption, most of the ash deposit being of co-ignimbrite rather than of Plinian fall origin [Rose and Chesner, 1987]. Thus the long-term (i.e., years to centuries) climatic impact of this huge eruption may have been negligible. If our estimate is correct, then it implies that the link previously proposed between the Toba eruption and the acceleration of ice growth and falling sea level [Rampino and Self, 1992] needs revision. These considerations, however, do not negate the possibility that the climate forcing agent for the acceleration of glacial conditions was of volcanic origin. For instance, Zielinski et al. [1996a,b] have identified a major acid signal in the GIPS2 ice core at around 71000 years. This $\mathrm{SO}_{4}^{2-}$ signal is more than 4 times higher than the one associated with the 1815 Tambora eruption (466 and $94 \mathrm{ppb}$, respectively), and on this basis, the corresponding climatic effects can be suspected to have been severe. Given the rather poor temporal resolution for dating acid signals of this age ( \pm 5000 in the range $40,000-100,000$ ), this large signal may also correspond to the cumulated effects of several volcanic eruptions of magnitude similar to the 
Krakatau or Pinatubo eruptions [see Zielinski et al. 1996b]. For instance, 10 eruptions of the size of Krakatau $\left(\mathrm{SO}_{4}{ }^{2-}\right.$ of 46 $\mathrm{ppb}$ in GISP2) occurring during a millennium, that is one every century, would have left an acid signal similar in magnitude to that identified by Zielinski et al. [1996] at 71,000 years. Clearly, the geologic imprints of such events would have less chance of being preserved compared with the huge caldera and deposits formed during the Toba eruption. Nevertheless, we stress that the potential atmospheric loading of the latter volcanic "super event" needs to be specifically addressed. In particular, a correct petrologic estimate of its sulfur yield conditions have to be performed. In a more general way, our results demonstrate that, before establishing potential connections between volcanic eruptions and climate changes, careful petrologic understanding of the ejecta is needed. As stressed 30 years ago by Carmichael [1967], a first-order inference about the redox state of silicic arc magmas can be obtained from the study of their mineralogy: reduced magmas lack, on average, amphibole and biotite, whereas oxidized ones crystallize them. Exceptions to this rule do occur, however, as illustrated by the Fish Canyon and Toba magmas: both have biotite and amphibole yet they differ in their respective $\mathrm{fO}_{2}$ by $\sim 1.5 \log$ unit (compare also Pinatubo and Santa María magmas).

\section{Conclusions}

The present work supports the proposal of Gerlach and coworkers that the preeruption magmas at many arc volcanoes coexist with a fluid phase at depth, and that much of the sulfur released during the eruption was stored within the fluid. We have shown, however, that this is true only for a specific range of redox conditions. Thus our work provides confirmation that the condition of fluid saturation is not exceptional in arc settings. The different cases studied above suggest that the amount of fluid phase needed to balance the sulfur deficit generally does not exceed $5 \mathrm{wt} \%$, which fits well with the estimates obtained from both the study of currently active volcanoes (Table 1) and theoretical calculations based on trace elements behavior [Wallace et al., 1995]. The experimental data presented here also help to explain the observed poor correlation between the erupted mass of magma and the sulfur output [Bluth et al., 1993]. From the standpoint of the $\mathrm{SO}_{2}$ contribution to the atmosphere by volcanoes, two broad categories of silicic magmas may be distinguished on the basis of their redox state, those below $\mathrm{NNO}+1$ and those above this redox threshold. The former will have sulfur yields that should correlate well with erupted masses, irrespective of the presence of a fluid phase, and should be calculable using the petrologic method. The second type of magma will have sulfur yields that will depend of the amount of fluid phase present in addition to the erupted mass of magma, all other factors being equal (temperature, melt composition). Although such oxidized magmas are mostly found in arc environments, the Santa María eruption illustrates the fact that not all arc volcanoes follow such a trend. Similarly, the comparison of the sulfur yields for Mount St. Helens and El Chichón shows that such a correlation may be difficult to establish in arc magmas. Indeed, although both erupted magmas had similar oxidation states, coexisted with a fluid phase, and both events were of the same magnitude in terms of explosivity, the sulfur output of the El Chichón eruption was an order of magnitude higher than that of St. Helens, although the latter had a sulfur partition coefficient 10 times higher than El Chichón (Table 1). This paradoxical result suggests that the dacite erupted at Mount St. Helens was intrinsically poor in sulfur, with a sulfur content lower than that needed for anhydrite saturation. Clearly, the bulk sulfur content of the magma at preeruption conditions, which is either a source-specific or a late acquired feature (i.e., through anhydrite contamination or from underlying degassing mafic magmas) will be also critical in determining the amount of sulfur loaded into the atmosphere. Finally, recognition that the sulfur release of silicic to intermediate magmas is strongly $\mathrm{fO}_{2}$ dependent has implications for the understanding of how Earth's atmosphere is affected by volcanic activity. This issue, however, can be addressed only with improvement in our understanding on how the redox states of the different envelopes that constitute the Earth have changed through geological times.

Aknowledgment. We thank $W$. Rose for providing us the compositions of FeTı oxides for the 1902 eruption of Santa Maria as well as additional information that helped constrain the preeruption conditions of this eruption. Thorough and helpful reviews were provided by James F. Luhr and Malcolm Rutherford and by the Associate Editor, $K$ Cameron. The editorial handling of $\mathrm{P}$. Davis is gratefully acknowledged.

\section{References}

Albarède, A., Introduction to Geochemical Modeling, Cambridge Univ. Press, New York, 1995.

Anderson, A. T., S. Newman, S.N. Williams, T.H. Druitt, C. Skirius, and E. Stolper, $\mathrm{H}_{2} \mathrm{O}, \mathrm{CO}_{2}, \mathrm{Cl}$, and gas in Plinian and ash-flow Bishop rhyolite, Geology, 17, 221-225, 1989.

Andres, R.J., W.I. Rose, P.R. Kyle, S. DeSilva, P. Francis, M. Gardeweg, and $\mathrm{H}$. Moreno Roa, Excessive sulfur dioxide emissions from Chilean volcanoes, J. Volcanol. Geotherm Res., 46, 323-329, 1991.

Baker, L.L., and M.J. Rutherford, Sulfur diffusion in rhyolitic melts, Contrib. Mineral. Petrol., 123, 335-344, 1996.

Beddoe-Stephens, B., J.A. Aspden, and T.J. Sheperd, Glass inclusions and melt compositions of the Toba Tuffs, northem Sumatra, Contrib. Mineral. Petrol., 83, 278-287, 1983.

Bernard, A., D. Demaiffe, N. Mattieli, and R. Punongbayan, Anhydritebearing pumice from Mount Pinatubo. Further evidence for the existence of sulphur rich silicic magmas, Nature, 354, 139-140, 1991.

Blake, S., C N.J. Wilson, I.E.M. Smith, and G.P.L. Walker, Petrology and dynamics of the Waimihia mixed magma eruption, Taupo volcano, New Zealand, J. Geol. Soc. London, 149, 193-207, 1992.

Bluth, G.J.S., C.C. Schnetzer, A.J. Krueger, and L.S. Walter, The contribution of explosive volcanism to global atmospheric sulphur dioxide concentrations, Nature, 366, 327-329, 1993.

Bluth, G.J.S., S.D. Doiron, A.J. Krueger, L.S. Walter, and C.C. Schnetzer, Global tracking of the $\mathrm{SO}_{2}$ clouds from the June, 1991 Mount Pinatubo eruptions, Geophys. Res. Lett., 21, 2833-2836, 1994.

Carmichael, I.S.E., The iron-titanium oxides of salic volcanic rocks and their associated ferromagnesian silicates, Contrib. Mineral. Petrol., 14, 36-64, 1967.

Carroll, M.R., and M.J. Rutherford, The stability of igneous anhydrite: Experimental results and implications for sulfur behavior in the 1982 El Chichón trachyandesite and other evolved magmas, J. Petrol., 28, 781-801, 1987

Carroll, M.R, and M.J. Rutherford, Sulfur speciation in hydrous experimental glasses of varying oxidation states: Results from measured wavelength shifts of sulfur x-rays, $\mathrm{Am}$. Mineral., 73, 845$849,1988$.

Casadevall, T.J., M.P. Doukas, C.A. Neal, R.G. McGimsey, and C.A Gardner, Emission rates of sulfur dioxide from Redoubt volcano, Alaska during the 1989-1990 eruptions, $J$. Volcanol. Geotherm. Res., 62, 519-530, 1994.

Chesner, C.A., Petrogenesis of the Toba Tuffs, Sumatra, Indonesia, $J$. Petrol., 39, 397-438, 1998

Chesner, C.A., W.I. Rose, A. Deino, R. Drake, and J.A. Westgate, 
Eruptive history of Earth's largest Quaternary caldera (Toba, Indonesia) clarified, Geology, 19, 200-203, 1991.

Clemente B., B. Scaillet, and M. Pichavant, Sulfur solubility in arcmagmas, Terra Nova, 9, 473, 1997.

Devine, J.D., H. Sigurdsson, and A.N. Davis, Estimates of sulfur and chiorine yield to the atmosphere from volcanic eruptions and potential clımatic effects, J. Geophys. Res., 89, 6309-6325, 1984.

Devine, J.D., J.E. Gardner, H.P. Brach, G.D. Layne, and MJ. Rutherford, Comparison of microanalytical methods for estimation of $\mathrm{H}_{2} \mathrm{O}$ contents of silicic volcanic glasses, Am. Mineral., 73, 845$859,1995$.

Dunbar, N. W., P.R. Kyle, and C.N.J. Wilson, Evidence for limited zonation in silicic magma systems, Taupo volcanic zone, New Zealand, Geology, 17, 234-236, 1989.

Evans, B.W., and M. Ghiorso, Thermodynamics and petrology of cummingtonite, Am. Mineral., 80, 649-663, 1995.

Evans, B. W, and B. Scaillet, The redox state of Pinatubo dacite and the ilmenite-hematite solvus, Am. Mineral., 82, 625-629, 1997.

Fierstein, J, and W. Hildreth, The Plinian eruptions of 1912 at Novarupta, Katmai National Park, Alaska, Bull. Volcanol., 54, 646684, 1992.

Fournelle, J., Anhydrite in Nevado del Ruiz November 1985 pumiceRelevance to the sulfur problem, J. Volcanol. Geotherm. Res., 42, 189-201, 1990.

Gerlach, T.M., Exsolution of $\mathrm{H}_{2} \mathrm{O}, \mathrm{CO}_{2}$, and $\mathrm{S}$ during eruptive episodes at Kilauea volcano, Hawaii, J. Geophys. Res., 91, 12177-12185, 1986.

Gerlach, T.M., and K A. McGee, Total sulfur dioxıde emissions and pre-eruption vapor-saturated magma at Mount St. Helens, 1980-88, Geophys. Res. Lett., 2l, 2833-2836, 1994.

Gerlach, T M., H.R. Westrich, T.J. Casadevall, and D.L. Finnegan, Vapor saturation and accumulation in magmas of the 1989-1990 eruption of Redoubt volcano, Alaska, $J$ Volcanol. Geotherm., Res. 62, 317-337, 1994.

Gerlach, T.M., H.R Westrich, and R.B Symonds, Pre-eruption vapor in magma of the climactic Mount Pinatubo eruption: Source of the giant stratospheric sulfur dioxide cloud, in Fire and Mud: Eruptions and Lahars of Mount Pinatubo, edited by C.G. Newhall and R. Punongbayan, pp. 415-434, Univ. of Wash. Press, Seattle, 1996.

Ghiorso, M.S., and R.O. Sack, Fe-Ti oxıde geothermometry: Thermodynamic formulation and the estimation of intensive variables in silicic magmas, Contrib. Mineral. Petrol., I08, 485-510, 1991.

Gourgaud, A., and J.C. Thouret, Magma mixing and petrogenesis of the 13 November 1985 eruptive products at Nevado del Ruiz (Colombia), J. Volcanol. Geotherm. Res., 42, 79-96, 1990.

Hammer, C. U, H B. Clausen, and W. Dansgaard, Greenland ice sheet evidence of post-glacial volcanism and its climatic impact, Nature. $288,230-235,1980$

Hansen, J., A. Lacis, R Ruedy, and M. Sato, Global surface temperature in 1995: Return to pre-Pinatubo level, Geophys Res. Lett, 23, 16651668, 1996.

Harington, C.R., The Year Without a Summer? World Climate in 1816, 576 pp., Can. Mus. Of Nat., Ottawa, 1992.

Haughton, D.R, P.L. Roeder, and B.J. Skinner, Solubility of sulfur in mafic magmas, Econ. Geol, 69, 451-467, 1974.

Hildreth, W., The Bıshop Tuff: Evidence for the origin of compositıonal zonation in silicic magma chambers, Spec. Pap Geol. Soc. Am , 180, 43-75, 1979.

Hildreth, W., The compositionally zoned eruption of 1912 in the valley of Ten Thousand Smokes, Katmai Natıonal Park, Alaska, $J$. Volcanol. Geotherm. Res., 18, 1-56, 1983.

Holloway, J.R, Fugacity and activity of molecular species in supercritical fluids, in Thermodynamics in Geology, edited by D G. Fraser, pp. 161-181, D. Reidel, Norwell, Mass, 1977.

Johnson, M. C., and M.J. Rutherford, Experimentally determined conditions in the Fish Canyon tuff, Colorado, magma chamber, $J$. Petrol., 30, 711-737, 1989

Kress, V., Magma mixing as a source for Pinatubo sulfur, Nature, 389, 591-593, 1997.

Krueger, A.J., L.S Walter, P.K. Bhartia, C.C. Schnetzler, N.A. Krotkov, I. Sprod, and G.J.S. Bluth, Volcanic sulfur dioxide measurements from the total ozone mapping spectrometer instruments, J. Geophys. Res., 100, 14057-14076, 1995.
Legrand, M., and R.J. Delmas, A 220 -years continuous record of volcanic $\mathrm{H}_{2} \mathrm{SO}_{4}$ in the Antarctic ice sheet, Nature, 327, 671-676, 1987.

Luhr, J.F., Experimental phase relations of water- and sulfur-saturated arc magmas and the 1982 eruptions of El Chichón volcano, $J$. Petrol., 31, 1071-1114, 1990.

Luhr, J.F., Volcanic shade causes cooling, Nature, 354, 104-105, 1991.

Luhr, J.F., I.S.E. Carmichael, and J.C. Varekamp, The 1982 eruptions of El Chichón volcano, Chiapas, Mexico. Mineralogy and petrology of the anhydrite-bearing pumıces, $J$. Volcanol. Geotherm. Res, 23, 69 $108,1984$.

Mandeville, C W., S Carey, and H. Sigurdsson, Magma mixing, fractional crystallization and volatile degassing during the 1883 eruption of Krakatau volcano, Indonesia, J. Volcanol. Geotherm. Res., 74, 243-274, 1996.

Matthews, S.J., A.P. Jones, and C.S. Bristow, A simple magma mixing model for sulphur behaviour in calc-alkaline volcanic rocks: Mineralogical evidence from Mount Pinatubo 1991 eruption, $J$. Geol. Soc London, 149, 863-866, 1992

Metrich, N., and R. Clochiatti, Sulfur abundance and its speciation in oxidized alkaline melts, Geochtm. Cosmochtm Acta, 60,4151-4160, 1996.

Métrich, N., H. Sigurdsson, P.S. Meyer, and J Devine,The 1783 Lakagigar eruption in Iceland: geochemistry, $\mathrm{CO}_{2}$ and sulfur degassing,Contrib. Mineral. Petrol., 107, 435-447 1991.

Moore, J.G., and B.P. Fabbi, An estimate of the juvenile sulfur content of basalt, Contrib. Mineral. Petrol., 33, 118-127, 1971.

Nilsson, K., and C.L. Peach, Sulfur speciation, oxidation state, and sulfur concentration in backarc magmas, Geochim. Cosmochim. Acta, 57, 3807-3813, 1993.

Palaıs, J. M., and H. Sigurdsson, Petrologic evidence of volatile emissions from major historic and pre-historic volcanic eruptions, in Understanding Climate Change, Geophys. Monog Ser. vol. 52, edited by A L. Berger, R.E. Dickinson, and J. Kidson, pp. 31-53, AGU, Washington, D.C.., 1989.

Pallister, J.S., R.P. Hoblitt, and A.G. Reyes, A basalt trigger for the 1991 eruptions of Pinatubo volcano, Nature, 356, 426-428, 1992.

Pallister, J.S., R P. Hoblitt, G.P. Meeker, C.G. Newhall, R.J. Knight, and D.F. Siems, 1996. Magma mixing at Mount Pinatubo volcano: Petrographical and chemical evidence from the 1991 deposits, in Fire and Mud: Eruptions and Lahars of Mount Pmatubo, edited by C.G. Newhall and R. Punongbayan, pp. 687-732, Univ. of Wash. Press, Seattle, 1996.

Rampino, M R., and S. Self, Sulphur-rich volcanic eruptions and stratospheric aerosols, Nature, 310, 677-679, 1984

Rampino, M. R., and S. Self, Volcanic winter and accelerated glaciation following the Toba super-eruption, Nature, 359, 50-52, 1992.

Rampino, M.R., R.B. Stothers, and S. Self, Climatic effects of volcanic eruptions, Nature. 313, 272, 1985

Rampino, M.R., S. Self, and R.B. Stothers, Volcanic winters, Annu Rev. Earth Planet. ScI., 16, 73-99, 1988

Rose, W. I., Santa María, Guatemala Bimodal, soda-rıch calc-alkalic stratovolcano, J. Volcanol. Geotherm Res., 33, 109-129, 1987.

Rose, W. I., and CA. Chesner, Dispersal of ash in the great Toba eruption, $75 \mathrm{ka}$, Geology, 15, 913-917, 1987.

Rutherford, M. J., and J. Devine, The May 18, 1980, eruption of Mount St. Helens, 3, Stability and chemistry of amphibole in the magma chamber, J. Geophys. Res., 93, 11949-11959, 1988.

Rutherford, M.J., and J. Devine, Pre-eruption pressure-temperature conditions and volatiles in the 1991 dacitic magma of Mount Pinatubo, in Fire and Mud: Eruptions and Lahars of Mount Pinatubo, edited by C. Newhall and R. Punongbayan, pp.751-766, Unıv. of Wash. Press, Seattle, 1996.

Scaillet, B, and B.W. Evans, The June 15, 1991 eruption of Mount Pinatubo, I, Phase equilibria and pre-eruption $\mathrm{P}-\mathrm{T}-\mathrm{fO}_{2}-\mathrm{fH}_{2} \mathrm{O}$ conditions of the dacite magma, J. Petrol., in press, 1998

Scaillet, B., M. Pichavant, J. Roux, G. Humbert, and A Lefèvre, Improvements of the Shaw membrane technique for measurement and control of $\mathrm{fH}_{2}$ at high temperatures and pressures, $\mathrm{Am}$. Mineral., 77, 647-655, 1992.

Schmidt, B.C., B. Scaillet, and F. Holtz, Accurate control of $\mathrm{fH}_{2}$ in cold seal pressure vessels with the Shaw membrane technique, Eur $J$ Mineral., 7, 893-903, 1995. 
Schnetzler, C.C., G.J.S. Bluth, A.J. Krueger, and L.S. Walter, A proposed volcanic sulfur index (VSI), J. Geophys. Res., 102, 2008720091, 1997.

Self, S., and A.J. King, Petrology and sulfur and chlorine emissions of the 1963 eruption of Gunung Agung, Bali, Indonesia, Bull. Volcanol., 58, 263-285, 1996

Self, S., Rampino, M R., Newton, M.S., and Wolff, J.A., Volcanological study of the great Tambora eruption of 1815, Geology, 12, 659-663, 1984.

Sigurdsson, H., S. Carey, J.M. Palais, and J. Devine, Pre-eruption compositional gradients and mixing of andesite and dacite erupted from Nevado del Ruiz volcano, Colombia in 1985, J. Volcanol. Geotherm. Res., 42, 127-151, 1990.

Sisson, T.W., and T.L. Grove, Experimental investigations of the role of $\mathrm{H}_{2} \mathrm{O}$ in calc-alkaline differentiation and subduction zone magmatism, Contrib. Mineral. Petrol., 113, 143-166, 1993.

Stothers R.B., The great Tambora eruption and its aftermath, Science, 224, 1191-1198, 1984

Swanson, S. E., C.J. Nye, T.P. Miller, and V.F. Avery, Geochemistry of the 1989-1990 eruption of Redoubt volcano, II, Evidence from mineral and glass chemistry, $J$. Volcanol. Geotherm. Res., 62, 453$468,1994$.

Symmonds, R. B., W.I. Rose, G.J.S. Bluth, and T.M. Gerlach, Volcanicgas studies: Methods, results, and applications, inVolatiles in Magmas, Rev. Mineral, vol. 30, edited by M.R. Carroll and J.R. Holloway, pp. 1-66, Am. Mineral. Soc., Washington, D.C., 1994.

Toulmin, P., and P.B. Barton Jr., A thermodynamic study of pyrite and pymhotite, Geochim. Cosmochim. Acta, 28, 641-671, 1964.

Tracy, R.J., and P. Robinson, Silicate-sulfide-oxide-fluid reactions in granulite-grade pelitic rocks, central Massachusetts, $\mathrm{Am}$. J. Sch, 288- $A, 45-74,1988$.

Varekamp, J.C., J.F. Luhr, and K.L. Prestegaard, The 1982 eruptions of El Chichón volcano (Chiapas, Mexico): Character of the eruptions, ash-fall deposits, and gasphase, J. Volcanol. Geotherm. Res., 23, 3968, 1984.

Walker, G. P. L., The Taupo pumice: Product of the most powerful (ultra-Plinian) eruption?, J. Volcanol. Geotherm. Res., 8, 69-94, 1980.

Wallace, P.J., and I.S.E. Carmichael, S speciation in submarine basaltic glasses as determined by measurements of SKa X-ray wavelength shifts, Am. Mineral., 79, 161-167, 1994.

Wallace, P.J., and T.M. Gerlach, Magmatic vapor source for sulfur dioxide released during volcanic eruptions: Evidence from Mount Pinatubo, Science, 265, 497-499, 1994.

Wallace, P.J., A.T. Anderson, and A.M. Davis, Quantification of preeruptive exsolved gas contents in silicic magmas, Nature, 377, 612615, 1995.

Warshaw, C. M., and R.L. Smith, Pyroxenes and fayalites in the Bandelier tuff, New Mexico: Temperatures and comparison with other rhyolites, Am. Mineral., 73, 1025-1037, 1990.
Watson, E.B., Diffusion in volatile-bearing magmas, in Volattles in Magmas, Rev. Mineral., vol. 30, edited by M.R. Carroll and J.R. Holloway, pp. 371-41 1, Am. Mineral. Soc., Washington, D.C., 1994.

Westrich, H.R., and T.M. Gerlach, Magmatic gas source for the stratospheric $\mathrm{SO}_{2}$ cloud from the June 15, 1991, eruption of Mount Pinatubo, Geology, 20, 867-870, 1992.

Westrich, H.R., H.W. Stockman, and J.C. Eichelberger, Degassing of rhyolitic magma during ascent and emplacement, J. Geophys. Res., 93, 6503-6511, 1988.

Westrich, H.R., J.C. Eichelberger, and R.L. Hervig, Degassing of the 1912 Katmai magmas, Geophys. Res. Lett , 18, 1561-1564, 1991.

Williams, S.T., N.C. Sturchio, M.L. Calvache, F. Ricardo Mendez, C. Adela Londoño, and P. Nestor Garcia, Sulfur dioxide from Nevado del Ruiz volcano, Colombia: Total flux and isotopic constraints on its origin, J. Volcanol. Geotherm. Res., 42, 53-68, 1990.

Williams, S. N., S.J. Schaefer, M.L. Calvache, and D. Lopez, Global carbon dioxide emission to the atmosphere by volcanoes, Geochim. Cosmochim. Acta, 56, 1765-1770, 1992.

Wilson, C. N. J., B.F. Houghton, M.O. McWilliams, M.A. Lanphere, S.D. Weaver, and R.M. Briggs, Volcanic and structural evolution of the Taupo volcanic zone: A review and synthesis, J. Volcanol. Geotherm. Res., 68, 1-28, 1995.

Zielinski, G. A., Stratospheric loading and optical depth estimates of explosive volcanism over the last 2100 years derived from the Greenland Ice Sheet Project 2 ice core, J. Geophys. Res., 100, 20937-20955, 1995.

Zielinski, G. A., P.A. Mayewski, L.D. Meeker, S. Whitlow, M.S Twickler, M. Morrison, D.A. Meese, A.J. Gow, and R.B. Alley, Record of volcanism since 7000 B.C. from the GISP2 Greenland Ice Core and implications for the volcano-climate system, Science, 264, 948-952, 1994.

Zielinski, G.A., P.A. Mayewski, L.D. Meeker, S. Whitlow, M.S. Twickler, and K. Taylor, Potential atmospheric impact of the Toba mega-eruption 71,000 years ago, Geophys. Res. Lett., 23, 837-840, 1996a.

Zielinski, G.A., P.A. Mayewski, L.D. Meeker, S. Whitlow, and M.S. Twickler, A 110000-yr record of explosive volcanism from the GISP2 (Greenland) ice core, Quat. Res., 45, 109-118, $1996 \mathrm{~b}$.

B. Clemente, M. Pichavant, and B. Scaillet, CRSCM, CNRS, 1A rue de la Férollerie, 45071 Orléans cedex 02, France. (bscaille@cnrs-orleans.fr) B.W. Evans, Department of Geological Sciences, Box 351310, University of Washington, Seattle, WA 98195-1310.

(evans@geology.washington.edu)

(Received November 18, 1997; Revised May 17, 1998; accepted June 23, 1998.) 